\title{
DEVELOPMENTAL FACTORS AFFECTING REGENERATION IN THE CENTRAL NERVOUS SYSTEM: EARLY BUT NOT LATE FORMED MITRAL CELLS REINNERVATE OLFACTORY CORTEX AFTER NEONATAL TRACT SECTION ${ }^{1}$
}

\author{
MARJORIE R. GRAFE ${ }^{2}$ \\ Department of Neuroscience and Center for Neurobiological Sciences, University of Florida College of Medicine, \\ Gainesville, Florida 32610
}

Received June 9, 1982; Revised October 4, 1982; Accepted October 8, 1982

\begin{abstract}
If the lateral olfactory tract (LOT) of the golden hamster is transected in the first week of postnatal life, axons will grow back through the cut and reinnervate the terminal regions. Functional recovery occurs only when the terminal regions are reinnervated. The experiments reported here tested the hypothesis that reinnervation is due to neogenesis: the continued growth of newly formed axons which were not severed by the lesion. In the first experiment the birth dates of the mitral and tufted cells were determined in the hamster. It was found that mitral cells are formed on gestational days 11 and 12 (E11 and E12) and tufted cells on E11 to E14. Experiment 2 involved the combination of $\left[{ }^{3} \mathrm{H}\right]$ thymidine labeling, for the time of cell formation, with the retrograde transport of horseradish peroxidase (HRP), at a time when the LOT projections are not yet complete. The axons of early formed cells were found to reach the olfactory cortex before those of later formed cells. Experiment 3 examined the possibility that the axons which grow through an early LOT transection are new axons that had not yet reached the level of the cut. Animals were given $\left[{ }^{3} \mathrm{H}\right]$ thymidine to label the times of formation of mitral and tufted cells and then were given a transection of the LOT on postnatal day 3 (P3). After a recovery period sufficient to allow axonal regrowth and reinnervation, HRP was placed in the olfactory projection region caudal to the prior LOT section. The original hypothesis was not supported. Cells that are formed early and send out their axons early are able to reinnervate the olfactory cortex, whereas late formed cells do not. The results of this experiment suggest that the factors which prevent the regrowth of axons when the LOT is cut after P7 may depend on the stage of development of the tissue into which the axons are growing, rather than in the cells of origin and their axons.
\end{abstract}

When projection tracts in the adult mammalian central nervous system (CNS) are severed, the fibers distal to the cut degenerate and no longer innervate their terminal fields appropriately (Ramon y Cajal, 1928). Specific functional deficits often accompany these lesions. When similar damage is suffered by an infant animal, the fibers

\footnotetext{
${ }^{1}$ I gratefully acknowledge the guidance and support of Dr. Christiana M. Leonard through all phases of this research. I thank Drs. W. E. Brownell, M. B. Heaton, K. M. Heilman, W. G. Luttge, J. W. Hinds, and M. Halpern for their comments and suggestions. This work was supported by National Institutes of Health Grant NS 13516 to Dr. Leonard and fulfilled part of the requirements for the degree of doctor of philosophy. The author was supported by a National Science Foundation predoctoral fellowship and a National Institute of Mental Health training grant to the Center for Neurobiological Sciences.

${ }^{2}$ Present address: Student Affairs Office, M105, Stanford Medical School, Stanford, CA 94305.
}

degenerate, but there is sometimes partial or complete recovery from the functional deficit. In several experiments it has been demonstrated that there is a correlated regrowth of axons and appropriate reinnervation of their terminal regions (Nygren et al., 1971; Devor, 1975; Small, 1977; Kalil and Reh, 1979). The present study was undertaken to identify the origin of axons reinnervating caudal olfactory regions after early tract section in the hamster pup.

The neonatal hamster olfactory system has considerable functional and anatomical plasticity. Devor (1976b) found that when the lateral olfactory tract (LOT) is cut prior to postnatal day 7 (P7), axons grow back through the cut and reinnervate the terminal regions. Functional recovery of thermotaxic behavior in pups (Small, 1977) and male mating behavior, which is olfactory dependent (Devor, 1975), occurs only in animals in which the ter- 
minal regions are reinnervated. When the LOT is cut after P7, this reinnervation does not occur, and there is no functional recovery.

The extensive literature on regeneration (for reviews see Ramon y Cajal, 1928; Windle, 1956; Bernstein and Goodman, 1973; Guth and Clemente, 1975) suggests that there are three possible sources for the reinnervating axons.

1. True regeneration (see Ramon y Cajal, 1928). There are few well documented examples of true axonal regeneration in either the mature or the immature CNS. There is evidence for axonal regeneration of the central adrenergic neurons in both the adult (Bjorklund et al., 1971; Stenevi et al., 1973) and younger animals (Nygren et al., 1971), but it occurs faster in the younger animals. Regeneration of pyramidal tract axons has been reported after lesions made in the first week of life (Kalil and Reh, 1979).

2. Collateral sprouting. Reinnervation could occur by fibers sprouting from the proximal portion of the transected axons (regenerative sprouting) or by collateral sprouting from nearby uninjured axons. Collateral sprouting from uninjured axons has been reported in many parts of the nervous system (for examples, see Hicks and d'Amato, 1970; Lynch et al., 1973; Price et al., 1976). In several systems, sprouting has been found from both the proximal part of the cut axons and from other nearby fibers (Pickel et al., 1974; Devor, 1976b; Kalil and Reh, 1979). Most of these studies find that sprouting occurs either exclusively, or to a much greater extent, in the young animal.

3. Neogenesis. The axons passing through the cut may represent continued growth of normal, newly formed axons which had not yet reached the level of the cut at the time of the tract section. A radical example of this process is the olfactory nerve, where there is a "reconstitution" of the nerve and its projections by axons of newly formed receptor cells following olfactory nerve section (Graziadei et al., 1979). Axonal neogenesis as an explanation for CNS regeneration in young animals was first suggested by Ranson (1903) and has been proposed as a mechanism for corticospinal plasticity (Bregman and Goldberger, 1982; in contrast with Kalil and Reh, 1979). In the visual system, aberrant projections resulting from early lesions appear to be due to continually growing new axons which are no longer receiving the appropriate positional signals (Guillery, 1972; Lund et al., 1973; So, 1979). It was therefore of interest to demonstrate whether in the neonatal olfactory system "reinnervation" was actually neogenesis.

The olfactory bulb and its projections to the olfactory cortical regions constitute a convenient system in which to examine the possibility that a developmental principle such as axonal neogenesis is related to functional recovery and neuroanatomical plasticity in young animals. The olfactory bulb is well laminated and has a discrete, easily identifiable population of cells which project centrally in the LOT to the anterior olfactory nucleus, olfactory tubercle, piriform cortex, and other basal forebrain regions (Devor, 1976a). The primary projection neurons from the bulb to the olfactory cortex are the mitral cells and the tufted cells located primarily in the external plexiform layer (EPL) (see Fig. 1).
The rodent olfactory system is behaviorally functional in the neonate (Devor and Schneider, 1974; Blass et al., 1977; Rudy and Cheatle, 1977; Crandall and Leonard, 1979) but undergoes both functional and anatomical changes during the first few weeks of postnatal life (Leonard, 1975, 1978; Singh and Nathaniel, 1977; Devor and Schneider, 1974). The postnatal establishment and expansion of the LOT projections in the rat and hamster have been well described (Leonard, 1975; Westrum, 1975; Singh, 1977; Schwob and Price, 1978). Since axon section must occur early in the period when the LO'T projection is establishing its distribution if functional recovery is to occur, it seemed likely that those fibers which grow through the LOT section prior to P7 are new axons that had not yet reached the level of the section, rather than regenerating axons or collateral sprouts.

In this study, $\left[{ }^{3} \mathrm{H}\right]$ thymidine autoradiography has been combined with the retrograde transport of HRP and neonatal lesions in an attempt to investigate directly possible correlations in the time of cell formation, the development of axonal projections, and their capacity for regrowth or regeneration. The use of $\left[{ }^{3} \mathrm{H}\right]$ thymidine autoradiographic techniques has provided much information about the time and place of origin of CNS cells and the paths that these cells follow in their migrations from site of origin to final position. The technique is limited, however, in that, by itself, it cannot give information about the connections of cells or the development of these connections. The combination of $\left[{ }^{3} \mathrm{H}\right]$ thymidine and HRP has been used previously to examine whether hippocampal cells with different birth dates ultimately project to different or to the same regions (Nowakowski et al., 1975) and to show that newly formed vomeronasal cells in the adult project to their appropriate target (Barber, 1981). The present study looks at whether individual cells within a region, that are known to project ultimately to similar areas, do so in a sequence which correlates with their time of origin.

\section{Materials and Methods}

\section{Experiment 1}

Time of cell formation. A series of pregnant hamsters (Mesocricetus auratus) was given intraperitoneal injections of $\left[{ }^{3} \mathrm{H}\right]$ thymidine (5 to $10 \mu \mathrm{Ci} / \mathrm{gm}$ ) on gestational days 10 (E10), E11, E12, E13, or E14. In order not to compromise the pregnancies, no injections were made on E15 or E16. Several pups were each injected subcutaneously with $\left[{ }^{3} \mathrm{H}\right]$ thymidine on postnatal days 1 or 2 , but no heavily labeled mitral or tufted cells were seen with these injections, and their data are not included in this report. A summary of the animals from which data were obtained and their specific treatments is given in Table I.

Animals were mated in the midafternoon (E0), thymidine injections were also given in the midafternoon on the days indicated, and birth usually occurred on the morning of E16 (P0). The pups were housed with their mothers in solid-bottom cages containing hardwood shavings until the time of sacrifice. At approximately 1 month of age (see Table I) the pups were sacrificed by transcardial perfusion of fixative ( $1 \%$ paraformaldehyde/ $1.25 \%$ glutaraldehyde) for $1 / 2$ hour, followed by $1 / 2$ hour 

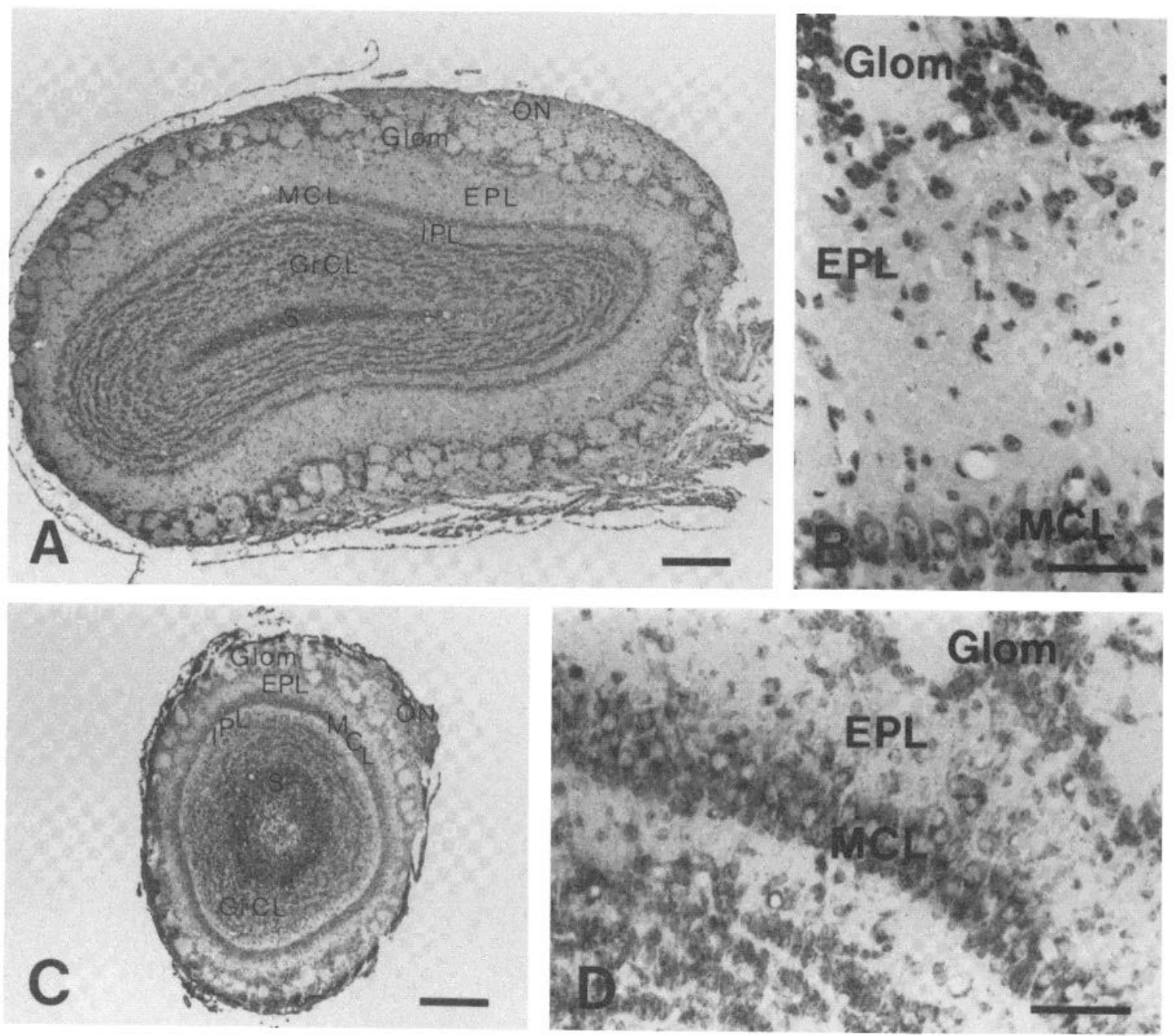

Figure 1. Coronal sections through the olfactory bulb of a hamster at 1 month of age ( $A$ and $B)$ and 4 days of age $(C$ and $D)$. Note the change in size and shape of the bulb between these ages and the changes in the width and cellular density of the mitral cell layer $(M C L)$ and the external plexiform layer $(E P L)$. The subventricular zone persists in the adult olfactory bulb (Hinds, 1968; Altman, 1969). $B$ and $D$ are higher power views of the MCL and EPL. Glom, glomerular layer; $G r C L$, granule cell layer; $I P L$, internal plexiform layer; $O N$, olfactory nerve layer; $S$, subventricular layer. Calibration bars: $A$ and $C, 250 \mu \mathrm{m} ; B$ and $D, 50$ $\mu \mathrm{m}$.

of $10 \%$ sucrose in $0.1 \mathrm{~m}$ phosphate buffer. The brains were removed, and the olfactory bulbs were separated from the rest of the brain. The bulbs were rinsed in phosphate buffer for 1 to $2 \mathrm{hrs}$ and then were dehydrated in a graded series of methanol and methanol:ethylene glycol monomethyl ether (1:1), cleared in methyl benzoate until sinking and in toluene ( 5 to $10 \mathrm{~min}$ only), then embedded in Paraplast Plus. The tissue was processed in this manner rather than by the conventional formalin fixation and ethanol dehydration to correspond with the brains in experiments 2 and 3. Ethanol dehydration of brains fixed with the paraformaldehyde/glutaraldehyde mixture resulted in very brittle, over-hardened tissue.

Coronal sections were cut at $8 \mu \mathrm{m}$ through the entire olfactory bulb. Serial sections were mounted onto acidcleaned chrom-alum slides, deparaffinized, and prepared for autoradiography with Kodak NTB-3 emulsion. The slides were allowed to expose for 8 weeks at $4^{\circ} \mathrm{C}$ and then were developed in Kodak D-19 developer and lightly counterstained with cresyl violet or neutral red. Exposure times of 3 to 6 weeks were considered initially, but the labeling was generally inferior compared to the 8-week exposure time.

\section{Experiment 2}

Correlation of cell birth date and axonal outgrowth. For this experiment, two days were chosen for $\left[{ }^{3} \mathrm{H}\right]$ thymidine injections: one early in the period of mitral and tufted cell formation (E11) and one late in this period (E13), as determined by the results of experiment 1 . (The following considerations were used to choose the injection date. On E10 so few mitral cells were labeled that the probability of finding double-labeled cells would be extremely low. On E14 mostly outer tufted cells were labeled, and it is not certain if all of these cells send efferent projections to the olfactory cortex (Lohman and Mentink, 1969; Haberly and Price, 1977).) Horseradish peroxidase (Sigma, Type VI) was placed in the olfactory tubercle, LOT, and/or piriform cortex of animals in both groups on P3. Several animals with $\left[{ }^{3} \mathrm{H}\right]$ thymidine injec- 
TABLE I

Animals and treatments

Only animals with verified complete tract section and effective HRP placements are included.

\begin{tabular}{|c|c|c|c|c|c|}
\hline $\begin{array}{l}\text { Animal } \\
\text { Number }\end{array}$ & $\begin{array}{l}\text { Day of }\left[{ }^{3} \mathrm{H}\right] \\
\text { Thy Injec- } \\
\text { tion }\end{array}$ & $\begin{array}{c}\text { Total amount } \\
\text { of }\left[{ }^{3} \mathrm{H}\right] \mathrm{Thy} \\
(\mu \mathrm{Ci} / \mathrm{gm})\end{array}$ & $\begin{array}{l}\text { LOT Sec- } \\
\text { tion }\end{array}$ & HRP & $\begin{array}{c}\text { Day of } \\
\text { Sacrifice }\end{array}$ \\
\hline $1382 \mathrm{~L} \quad(\mathbf{E})^{a}$ & E10 & $10^{b}$ & $-{ }^{c}$ & - & P10 \\
\hline $1470 \mathrm{~L} \quad(\mathrm{E})$ & E10 & $10^{b}$ & - & - & $\mathrm{P} 49$ \\
\hline $1471 \mathrm{~L} \quad(\mathrm{E})$ & E10 & $10^{b}$ & - & - & P49 \\
\hline $1128 \mathrm{~L} \quad$ (A) & E11 & 5 & - & - & P30 \\
\hline $1324 \mathrm{~L} \quad$ (B) & E11 & 10 & - & - & $\mathrm{P} 26$ \\
\hline $1325 \mathrm{~L} \quad$ (B) & E11 & 10 & - & - & $\mathrm{P} 26$ \\
\hline $1511 \mathrm{~L} \quad(\mathrm{~F})$ & E12 & $10^{b}$ & - & - & P10 \\
\hline $1512 \mathrm{~L} \quad(\mathrm{~F})$ & E12 & $10^{b}$ & - & - & P10 \\
\hline $1560 \mathrm{~L} \quad(\mathrm{~F})$ & E12 & $10^{b}$ & - & - & $\mathrm{P} 29$ \\
\hline $1560 \mathrm{R} \quad(\mathrm{F})$ & E12 & $10^{b}$ & - & - & P29 \\
\hline $1381 \mathrm{~L} \quad$ (D) & E13 & $8^{b}$ & - & - & P10 \\
\hline $1468 \mathrm{~L} \quad$ (D) & E13 & $8^{b}$ & - & - & P49 \\
\hline $1469 \mathrm{~L} \quad(\mathrm{D})$ & E13 & $8^{b}$ & - & - & P49 \\
\hline $1354 \mathrm{~L} \quad$ (C) & E14 & 10 & - & - & P36 \\
\hline $1354 \mathrm{R} \quad$ (C) & E14 & 10 & - & - & P36 \\
\hline $1353 \mathrm{~L} \quad$ (C) & E14 & 10 & - & - & P36 \\
\hline 1353R (C) & E14 & 10 & - & - & P36 \\
\hline $1546 \mathrm{~L} \quad(\mathrm{I})$ & E11 & $10^{b}$ & - & $\mathrm{P3}$ & P4 \\
\hline $1547 \mathrm{~L} \quad$ (I) & E11 & $10^{b}$ & - & P3 & $\mathrm{P} 4$ \\
\hline $1553 \mathrm{~L} \quad$ (J) & E11 & $9^{b}$ & - & P3 & $\mathrm{P} 4$ \\
\hline $1554 \mathrm{~L} \quad(\mathrm{~J})$ & E11 & $9^{b}$ & - & P3 & $\mathrm{P} 4$ \\
\hline $1502 \mathrm{~L} \quad(\mathrm{H})$ & E13 & $8^{b}$ & - & P3 & $\mathrm{P} 4$ \\
\hline $1503 \mathrm{~L} \quad(\mathrm{H})$ & E13 & $8^{b}$ & - & P3 & $\mathrm{P} 4$ \\
\hline $1505 \mathrm{~L} \quad(\mathrm{H})$ & E13 & $8^{b}$ & - & P3 & $\mathrm{P} 4$ \\
\hline $1556 \mathrm{~L} \quad(\mathrm{~K})$ & E13 & $8^{b}$ & - & $\mathrm{P3}$ & P4 \\
\hline $1487 \mathrm{~L} \quad$ (D) & E13 & $8^{b}$ & - & P53 & P54 \\
\hline $1601 \mathrm{~L} \quad(\mathrm{H})$ & E13 & $8^{b}$ & - & P30 & P31 \\
\hline $1687 \mathrm{~L} \quad(\mathrm{~K})$ & E13 & $8^{b}$ & - & P36 & P37 \\
\hline $1749 \mathrm{~L} \quad(\mathrm{~L})$ & E13 & $8^{b}$ & - & P26 & $\mathrm{P} 27$ \\
\hline $17501 \quad$ (L) & E13 & $8^{L}$ & - & $\mathrm{P} 26$ & $\mathrm{P} 27$ \\
\hline $1670 \mathrm{~L} \quad(\mathrm{~J})$ & E11 & $9^{b}$ & P3 & P34 & P35 \\
\hline $1674 \mathrm{~L} \quad$ (J) & E11 & $9^{b}$ & P3 & P37 & P38 \\
\hline $1675 \mathrm{~L}$ (J) & E11 & $9^{b}$ & $\mathrm{P} 3$ & P37 & P38 \\
\hline $1684 \mathrm{~L} \quad(\mathrm{~J})$ & E11 & $9^{b}$ & P3 & P39 & $\mathrm{P} 40$ \\
\hline $1579 \mathrm{~L} \quad(\mathrm{G})$ & E13 & $8^{b}$ & P3 & P30 & P31 \\
\hline $1580 \mathrm{~L} \quad(\mathrm{G})$ & E13 & $8^{b}$ & P3 & P39 & P31 \\
\hline $1743 \mathrm{~L} \quad(\mathrm{~L})$ & E13 & $8^{b}$ & P3 & $\mathrm{P} 25$ & $\mathrm{P} 26$ \\
\hline $1747 \mathrm{~L} \quad(\mathrm{~L})$ & E13 & $8^{b}$ & P3 & $\mathrm{P} 26$ & P27 \\
\hline
\end{tabular}

"Litter identification is given in parentheses.

${ }^{b}$ In two doses, $1 \mathrm{hr}$ apart.

c-, not performed.

tions on E13 received HRP injections at about 1 month of age (see Table I).

For the HRP placement, a small pellet (approximately $0.3 \mathrm{~mm}$ diameter) of $80 \% \mathrm{HRP}$ in saline was dried onto the tip of a 50- $\mu \mathrm{m}$ diameter wire. One eye was removed and a small hole was made in the medial wall of the orbit, and the tip of the wire containing the HRP was placed in the desired region under direct visualization. The insertion wire was left in place for 2 to 3 min to allow the HRP to dissolve away from it and then was gently removed. The 3-day-old animals were anesthetized by immersion in crushed ice; the older animals were anesthetized by intraperitoneal injection of Chloropent,
$0.0038 \mathrm{ml} / \mathrm{gm}$. Bleeding was controlled as necessary with saline- or thrombin-soaked Gelfoam. The wounds were closed with Steristrips or sutures, and the skin was carefully cleaned to reduce postsurgical cannibalism by the mother. When all pups in a litter had recovered from the anesthesia, the younger pups were returned to the mother. The older animals were housed separately after surgery. All animals were allowed to survive for $24 \mathrm{hr}$ after the HRP placement.

The animals were sacrificed as in experiment 1 . After removal from the skull, the olfactory bulbs were separated from the rest of the brain and processed separately. The brains were immersed in sucrose/buffer overnight at $4^{\circ} \mathrm{C}$, then embedded in gelatin/albumen with glutaraldehyde $(0.5 \mathrm{ml}$ of glutaraldehyde per $10 \mathrm{ml}$ of gelatin/ albumen) for 2 to $4 \mathrm{hr}$. Frozen sections were cut on a sliding microtome at $50 \mu \mathrm{m}$ in the coronal plane. To determine the location of the HRP injection site, equidistant sections were reacted with either tetramethylbenzidine (Mesulam, 1978) or diaminobenzidine (DAB) with cobalt chloride enhancement (Adams, 1977) and counterstained with neutral red.

To identify retrogradely labeled cells, the olfactory bulbs were reacted with $\mathrm{DAB}$, en bloc, as described below (modified from Moody and Heaton, 1981). The times indicated for each step are for 4- and 30-day-old olfactory bulbs, respectively. The en bloc reaction works well in embryonic and neonatal tissue, but the DAB does not penetrate older tissue well, requiring extremely long reaction times. The size of the tissue block did not seem to be a major factor, within the range of this experiment. The steps were as follows: (1) rinse twice in phosphate buffer, $\mathrm{pH} 7.3$ (15 and $30 \mathrm{~min}$ each); (2) rinse in $0.1 \mathrm{M}$ Tris- $\mathrm{HCl}$ buffer, $\mathrm{pH} 7.6$ (15 and $30 \mathrm{~min}$ ); (3) $0.5 \% \mathrm{CoCl}_{2}$ in Tris buffer ( $60 \mathrm{~min}$ and $2 \mathrm{hr}$ ); (4) rinse twice in $0.1 \mathrm{M}$ Tris buffer (15 and $30 \mathrm{~min}$ each); (5) rinse in $0.1 \mathrm{M}$ phosphate buffer, pH 7.3 (15 and $30 \mathrm{~min}$ ); (6) 0.05 to $0.1 \%$ DAB in phosphate buffer at $4^{\circ} \mathrm{C}(60 \mathrm{~min}$ and $3 \mathrm{hr}) ;(7)$ 0.01 to $0.02 \% \mathrm{H}_{2} \mathrm{O}_{2}$ in DAB (60 min and $4 \mathrm{hr}$ or more); (8) rinse twice in phosphate buffer (15 and 30 min each). The tissue was then dehydrated and embedded, and prepared for autoradiography as in experiment 1.

\section{Experiment 3}

Early transection of the lateral olfactory tract. Animals that had received $\left[{ }^{3} \mathrm{H}\right]$ thymidine on E11 or E13 were given a transection of the lateral olfactory tract on P3. The region around the LOT was exposed, and a small cut through the LOT was made using a microknife, taking care not to cause unnecessary additional damage. After surgery the pups were returned to the mother for 3 to 4 weeks, an interval more than sufficient to allow reinnervation of the olfactory cortex by the olfactory bulb efferents (Devor, 1976b; Small, 1977). When the pups were about 1 month old, they received injections of HRP into the olfactory projection areas caudal to the prior LOT section. The location of the LOT section was identified first by scar formation on the skull and then by direct visualization of the residual portion of the LOT rostral to the cut. The LOT was not visible as a distinct bundle caudal to a complete transection. The animals were sacrificed and the tissue was reacted with $\mathrm{DAB}$ and 
processed for autoradiography as described in the two previous experiments. Because of the multiple procedures combined in these experiments, large numbers of animals were used to produce the groups from which data were obtained, as listed in Tables I to III. The animals from which data are reported are only those with adequate $\left[{ }^{3} \mathrm{H}\right]$ thymidine labeling, histologically verified complete LOT sections, and satisfactory HRP injections in the olfactory projection areas.

\section{Data collection and analysis}

Camera lucida drawings were made of olfactory bulb (OB) sections at a magnification of $\times 125$. Mitral and tufted cells were identified on the basis of their size, large nucleus and abundant cytoplasm, and position in the mitral cell layer (MCL) or EPL. Only cells whose nucleus was clearly in the plane of section were counted. The sections were examined under the microscope at $\times 600$ for the presence of cells labeled with $\left[{ }^{3} \mathrm{H}\right]$ thymidine and/ or HRP (Fig. 2). Cells which had many silver grains (generally greater than $\times 10$ background) over the nucleus were considered "heavily labeled" with thymidine and were presumed to have undergone their last division on the day of $\left[{ }^{3} \mathrm{H}\right]$ thymidine injection. A thorough discussion of the problems in defining "heavily labeled" cells can be found in Sidman (1970).

The HRP reaction product is seen as a dark brown particulate substance in the cytoplasm of the cell body and proximal dendrites. The two labels are easily distinguished under the microscope on the basis of their locations in the cell $\left(\left[{ }^{3} \mathrm{H}\right]\right.$ thymidine in the nucleus, HRP in cytoplasm), color and size $\left(\left[{ }^{3} \mathrm{H}\right]\right.$ thymidine appears as small, distinct black grains; HRP appears as larger, dark brown particles), and plane of focus (silver grains for $\left[{ }^{3} \mathrm{H}\right]$ thymidine are in the emulsion above the section, HRP reaction product is within the cell). The positions of $\left[{ }^{3} \mathrm{H}\right]$ thymidine- and HRP-labeled cells were indicated on the camera lucida drawings. Labeled granule cells and glia were not included on the drawings. For each olfactory bulb analyzed in experiment 1 , five sections were drawn: rostral $\mathrm{OB}$, two sections in mid-OB, caudal $\mathrm{OB}$, and a caudal section which contained the accessory olfactory bulb. In experiments 2 and 3 , two sections in the mid-OB were drawn for each brain, since no rostral-caudal differences were found in experiment 1.

The position of each labeled cell within the EPL was determined in the following manner. The distance from the outer edge of the MCL to the labeled cell and the distance from the MCL to the inner edge of the glomerular layer were measured. The ratio $(r)$ of these distances was calculated. An $r$ of 0 indicates a cell in the MCL; an $r$ of 1.0 indicates a cell in the glomerular layer (see Fig. 5). For each section drawn, the mean $r(\bar{r})$ and mean EPL depth were calculated. An overall $\bar{r}$ was then determined for each olfactory bulb.

Additional measurements were made on the sections from experiments 2 and 3 and on the mid-OB sections from the E11 and E13 brains in experiment 1. The total number of all mitral and tufted cells per section was counted (both labeled and unlabeled cells), and the perimeter of the outer edge of the MCL was measured. The numbers of mitral cells per unit perimeter, tufted cells per perimeter, and total cells per perimeter were calculated, and the ratio of mitral to tufted cells was determined. The proportion of $\left[{ }^{3} \mathrm{H}\right]$ thymidine-labeled cells to total mitral and tufted cells was also calculated for these sections $(p(t h y))$.

The location and extent of the site of HRP placement was determined for each animal in experiments 2 and 3 (Fig. 3). Cell counts for $\left[{ }^{3} \mathrm{H}\right]$ thymidine-labeled and total cells, as well as HRP-labeled cells, were made only in brains that had HRP injections in the olfactory projection regions which were of a size sufficient to produce retrograde labeling of a reasonable number of olfactory bulb cells (Grafe and Leonard, 1982). In experiment 3, the site of LOT transection was verified in histological sections, and only those animals with complete tract sections were included in the analysis. Caudal to the level of the cut, the LOT was completely absent as a bundle on the surface of the brain, and there was usually some distortion of the underlying cortex at the cut (Figure 4).

For experiments 2 and 3, approximately 100 (experiment 2) to 400 (experiment 3 ) sections from each olfactory bulb were examined under the microscope at $\times 600$ for the presence of HRP-labeled and double-labeled cells. Using the total number of cells per section counted as above, the proportion of HRP-labeled cells to total cells was calculated ( $p(\mathrm{HRP}))$. Assuming that there is no interaction between the presence of $\left[{ }^{3} \mathrm{H}\right]$ thymidine and that of HRP in the cells, the predicted incidence of both labels in the same cell can be calculated as: $p$ (doublelabeled, predicted $)=p($ HRP $) \times p(t h y)$. This was compared to the actual number of double-labeled cells identified. Deviation from the predicted value indicates some interaction of the presence of $\left[{ }^{3} \mathrm{H}\right]$ thymidine label (time of cell formation) and HRP label (time the axon reaches the projection areas).

\section{Results \\ Experiment 1}

Results. Heavily labeled mitral and tufted cells were found with $\left[{ }^{3} \mathrm{H}\right]$ thymidine injections on E10, E11, E12, E13, and E14, but not on P1 or P2. Following $\left[{ }^{3} \mathrm{H}\right]$ thymidine injection on E10, only a very few mitral cells were heavily labeled (five cells in 14 sections, three animals). Mitral cells apparently undergo their last division primarily on E11 and E12. No labeled mitral cells were seen following injections on E13 or E14. Tufted cells were formed on E11 to E14. Inner tufted cells were formed predominantly on E11 and E12, middle tufted cells on E12 and E13, and outer tufted cells on E13 and E14. Because we did not inject animals on E15 or E16 (day of birth), the termination of the period of outer tufted cell formation is uncertain.

The depth analysis shows that there is an outward progression of the positions of cells formed from E10 to E14 (Fig. 5). The overall $\bar{r}$ values for each date of injection are: $\mathrm{E} 10=0$; $\mathrm{E} 11=0.03$ (the $N$ for individual animals ranged from 25 to $37, \mathrm{SEM}=0.003$ to 0.020$) ; \mathrm{E} 12=0.39$ $(N=164$ to $208, \mathrm{SEM}=0.024$ to 0.028$) ; \mathrm{E} 13=0.72(N$ $=93$ to 219, SFM $=0.012$ to 0.023$) ; \mathrm{E} 14=0.86(N=90$ to $152, \mathrm{SEM}=0.011$ to 0.014 ). At each age there was a range of cell positions, but the overall variability was quite low. In Figure 5, the standard errors of the means 

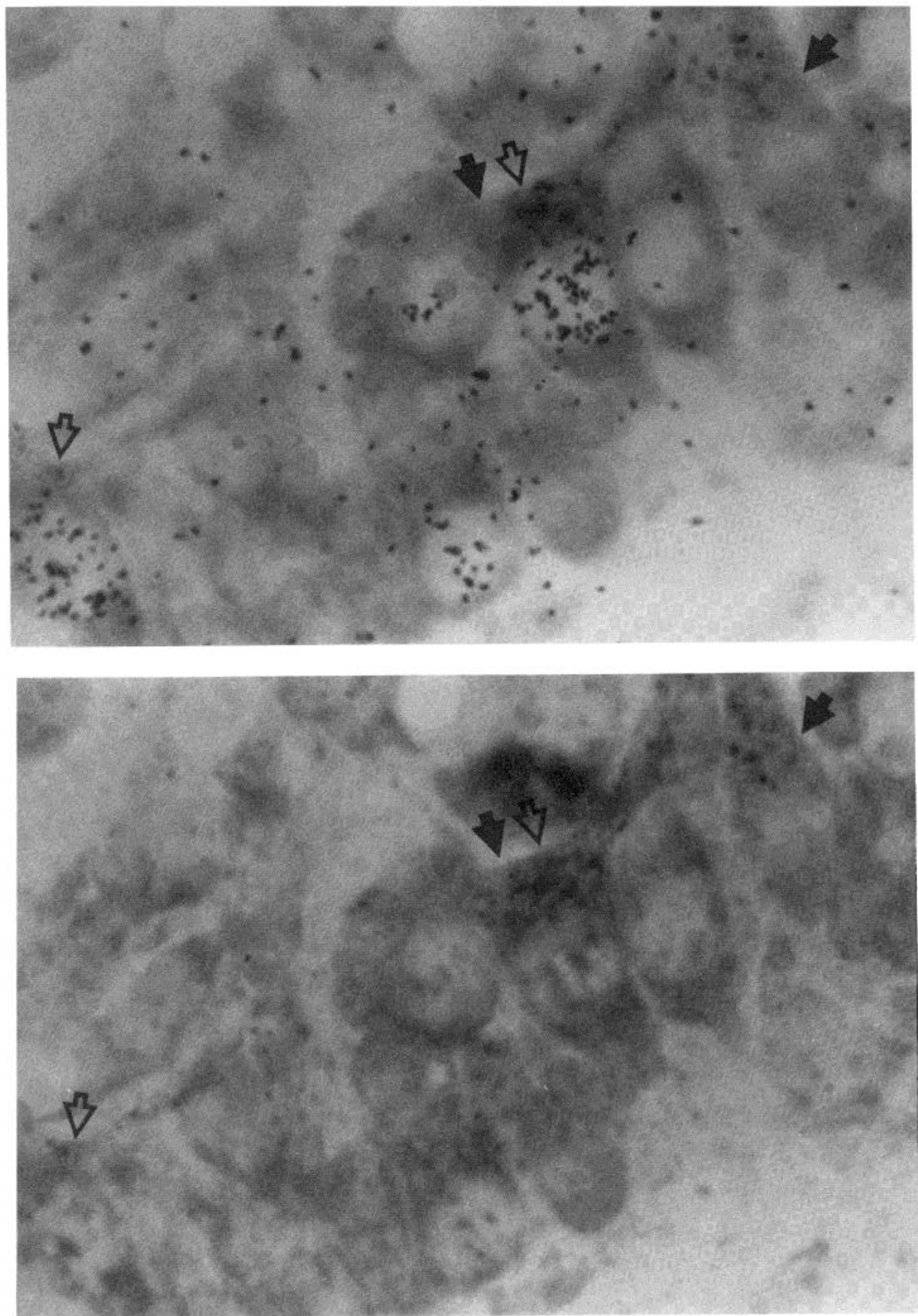

Figure 2. High power photomicrograph of cells in the mitral cell layer of an animal injected with $\left[{ }^{3} \mathrm{H}\right]$ thymidine on E11 and with HRP on P3. The plane of focus in the upper half of the figure is through the emulsion above the tissue, while that in the lower half is through the tissue itself. The $\left[{ }^{3} \mathrm{H}\right]$ thymidine label is seen as silver grains in the emulsion (upper). Heavily labeled cells have many silver grains above their nuclei. The HRP reaction product is a particulate substance in the cytoplasm (lower). There are many unlabeled cells, a cell labeled with $\left[{ }^{3} \mathrm{H}\right]$ thymidine only (open arrow, lower left), a cell with HRP label only (solid arrow, upper right), and one double-labeled cell (double arrows). DAB reaction, counterstained with neutral red.

are within the boundaries of the circles for all animals. We found no consistent regional differences within the bulb in the times of mitral and tufted cell formation, but our sample size may have been too small to demonstrate subtle differences.

\section{Experiment 2}

Rationale. Animals with $\left[{ }^{3} \mathrm{H}\right]$ thymidine injections on E11 or E13 were each given injections of HRP into the olfactory bulb projection areas on P3. The numbers of mitral and tufted cells with $\left[{ }^{3} \mathrm{H}\right]$ thymidine label, HRP label, and both thymidine and HRP labels, and the total numbers of unlabeled mitral and tufted cells were counted. On P3, the efferent projections from the bulb are still incomplete (Leonard, 1975; Schwob and Price, 1978; Grafe and Leonard, 1982). The HRP injections on P3 will label the olfactory bulb cells whose axons enter the lateral olfactory tract and innervate the terminal 

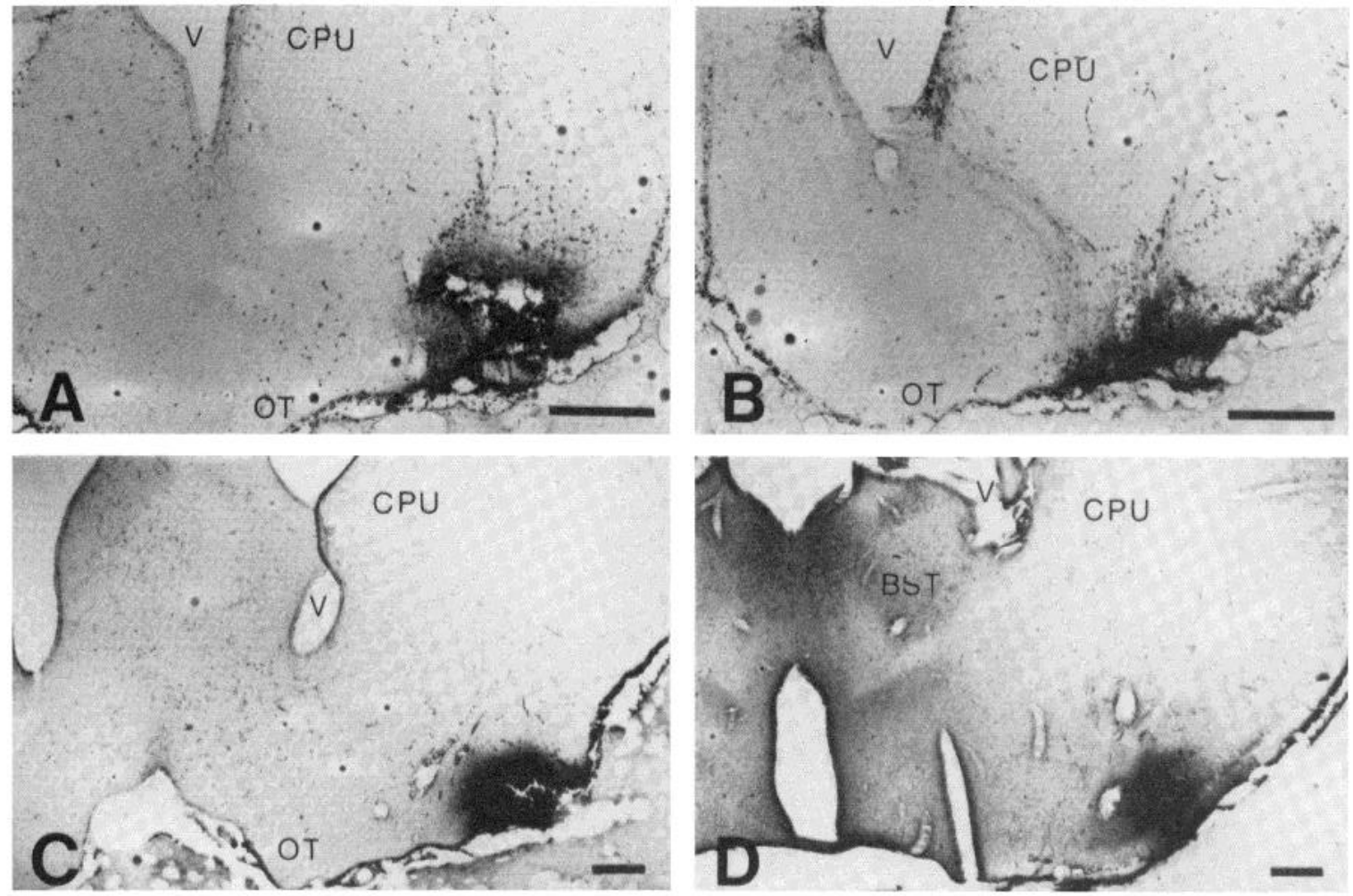

Figure 3. Examples of HRP placement sites for experiments 2 and 3. A, Animal 1553, given $\left[{ }^{3} \mathrm{H}\right]$ thymidine on E11 and $\mathrm{HRP}$ on P3. HRP placement was in the ventral piriform cortex and just deep to the lateral olfactory tract (LOT), at the level of the caudal olfactory tubercle. $B$, Animal 1556, given $\left[{ }^{3} \mathrm{H}\right]$ thymidine at E13 and HRP at P3. HRP placement was in and surrounding LOT, at a more rostral level than in $A$. $C$, Animal 1674 , given $\left[{ }^{3} \mathrm{H}\right]$ thymidine on E11, LOT on P3, and HRP at 1 month. HRP placement was in and surrounding LOT, at the level of the midolfactory tubercle. $D$, Animal 1743 , given $\left[{ }^{3} \mathrm{H}\right]$ thymidine on E13, LOT on P3, and HRP at 1 month. HRP placement was in the caudal piriform cortex. BST, bed nucleus of the stria terminalis; $C P U$, caudate putamen; $O T$, olfactory tubercle; $V$, lateral ventricle. All brains reacted with $\mathrm{DAB} ; D$ is lightly counterstained with neutral red, $A$ to $C$ have no counterstain. Calibration bars, $500 \mu \mathrm{m}$.

regions early in the course of development of this projection. If there is no interaction between the time of cell formation and the time the axon reaches the projection areas $p$ (double-labeled, predicted $)=p(\mathrm{HRP}) \times p($ thy $)$. The hypothesis was that the earlier formed cells send out their axons earlier, leading to the prediction that there would be more double-labeled cells in the E11 group than in the E13 group.

Results. Table II indicates for each animal the number and percentage of HRP- and $\left[{ }^{3} \mathrm{H}\right]$ thymidine-labeled cells, and the predicted and actual proportions of cells containing both labels. For each animal in the E11, HRP P3 group, the actual number of double-labeled cells is about twice the predicted value. In the E13, HRP P3 group, three animals had fewer than predicted double-labeled cells (about one-fifth the predicted value), and one animal had no cells containing both labels. The presence of double-labeled cells in brains of the E13 group which had HRP injections at 1 month of age confirmed that cells formed on E13 eventually send their axons into the projection areas and maintain these connections. Thus these results support the hypothesis that the time of axonal innervation of terminal regions correlates with the time of cell birth.

A comparison of the depth distribution of $\left[{ }^{3} \mathrm{H}\right]$ thymidine-labeled cells between the animals in this experiment sacrificed on P4 and those in this and the previous experiment sacrificed at 1 month shows that $\bar{r}$ is significantly lower in the E13, P4 group than in the E13, 1 month group (Fig. 6; 0.59 versus $0.72, t=3.26 p<0.005$ ). There was no difference in $\bar{r}$ between E11, P4 and E11, 1 month $(\bar{r}=0.04, \bar{r}=0.03$, respectively). The cells formed on E13 apparently have not yet reached their final positions in the EPL by P4, whereas those formed on E11 have already completed their migration.

When all of the olfactory bulb projection neurons (labeled and unlabeled) are considered, the ratio of all mitral cells to tufted cells also changes significantly between P4 and 1 month. The ratio of mitral to tufted cells for $\left[{ }^{3} \mathrm{H}\right]$ thymidine E11 animals is 4.14 at $\mathrm{P} 4$ and 0.74 at 1 month $(t=13.1, p<0.001)$. The ratio for $\left[{ }^{3} \mathrm{H}\right]$ thymidine E13 animals is 6.23 at $\mathrm{P} 4$ and 0.72 at 1 month $(t=16.4$, $p<0.001$ ). Figure 7 shows that at $\mathrm{P} 4$ (open bars) there are many more mitral than tufted cells, but by 1 month (solid bars) this ratio is reversed, so that there are more tufted than mitral cells. This reflects the fact that the MCL is several cells thick at P4 but thins to a single cell layer by 1 month (see Fig. 1). The changes in the direction of the ratio indicate that some cells in the MCL at P4 are no longer in that position at 1 month, and the thinning of the MCL is not simply due to an expansion of the perimeter of the bulb. Surprisingly, at $\mathrm{P} 4$, there are more total cells present in the MCL if the animal has received a $\left[{ }^{3} \mathrm{H}\right]$ thymidine injection on E13 rather than on E11. 

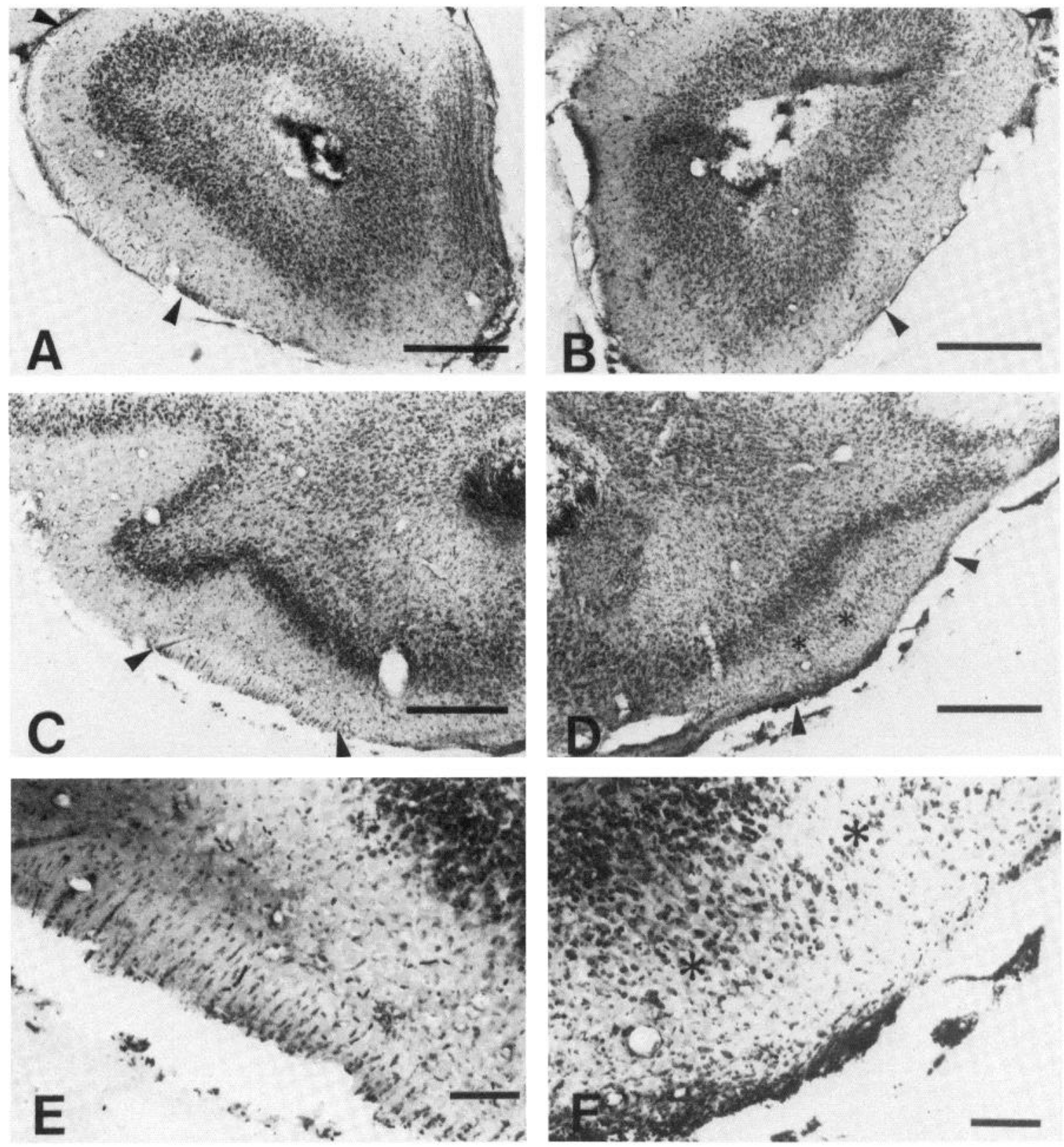

Figure 4. Site of lateral olfactory tract (LOT) transection of animal 1743, given LOT on P3 and sacrificed at 1 month of age. $A$, $C$, and $E$ are from the right (normal) side of the brain. $B, D$, and $F$ are from the left (operated) side. $A$ and $B$, Sections through the olfactory peduncle, rostral to the site of LOT transection. The LOT can be seen between the two arrowheads. In $A$, the normal LOT is a pale region on the surface of the brain, easily identified by the rows of glial nuclei. In $B$, the LOT rostral to the transection is somewhat reduced, and the glial nuclei are more disordered. $C$ to $F$, Sections through the rostral olfactory tubercle, at the level of the cut. In $C$, the LOT is a discrete bundle of fibers (between arrowheads). $D$, The LOT is completely absent on the operated side. There is some glial scarring near the pial surface, and some aberrant cell groups are seen deep to where the LOT would be found (asterisks). E, Higher power view of region between arrowheads in C.F. Higher power view of the region between the arrowheads in $D$. All sections were counterstained with neutral red. Calibration bars $A$ to $D, 500 \mu \mathrm{m} ; E$ and $F, 100$ $\mu \mathrm{m}$.

Apparently, the injection of $\left[{ }^{3} \mathrm{H}\right]$ thymidine on E13 affects the positions of cells in (or passing through) the MCL on P4 (M. R. Grafe, submitted for publication).

\section{Experiment 3}

Rationale. Transection of the LOT at P3 allows some bulb efferents to reinnervate the olfactory cortex caudal to the cut, and the density of innervation rostral to the cut is increased (Devor, 1976b). This experiment was performed to test the hypothesis that the fibers that grow through the cut are new fibers which had not yet reached the level at which the tract was sectioned. Experiment 2 demonstrated that the earlier formed cells send their axons into the projection areas first. For this experiment, the assumption is that the later formed cells send their axons out last-a hypothesis which could not be directly 


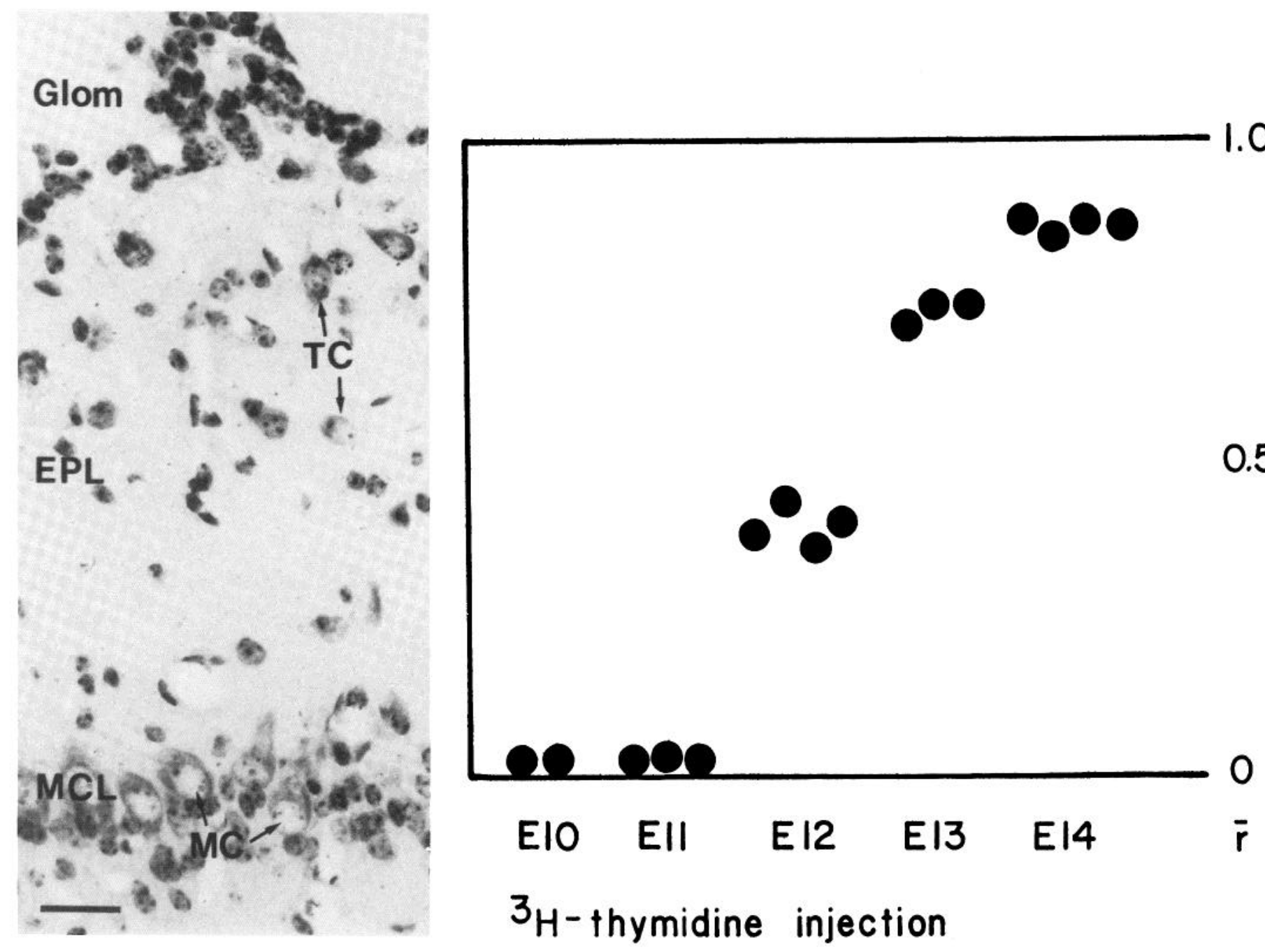

Figure 5. Left, Photomicrograph of the MCL and EPL of a hamster olfactory bulb, showing locations of mitral and tufted cells. $E P L$, external plexiform layer; Glom, glomerular layer; $M C$, mitral cell; $M C L$, mitral cell body layer; $T C$, tufted cell. Calibration bar, $25 \mu \mathrm{m}$. Right, Representation of MCL and EPL, indicating average positions $(\bar{r})$ of heavily labeled cells following $\left[{ }^{3} \mathrm{H}\right]$ thymidine injections on E10 to E14. All animals were sacrificed at about 1 month of age. Each circle represents $\bar{r}$ for one animal (SEM is within the boundaries of each circle for this experiment). See the text ("Materials and Methods") for explanation.

TABLE II

Numbers of cells labeled with HRP and $\left[{ }^{3} \mathrm{H}\right]$ thymidine $\left(\left[{ }^{3} \mathrm{H}\right] \mathrm{Thy}\right)$ after HRP placement on $P$

\begin{tabular}{|c|c|c|c|c|c|c|}
\hline \multirow{2}{*}{ Treatment $^{a}$} & \multirow{2}{*}{ Brain } & \multirow{2}{*}{$\begin{array}{l}\text { HRP-labeled cells/Section } \\
\qquad(\%)\end{array}$} & \multirow{2}{*}{$\begin{array}{c}{\left[{ }^{3} \mathrm{H}\right] \text { Thy-labeled Cells/ }} \\
\text { Section (\%) }\end{array}$} & \multicolumn{2}{|c|}{$\begin{array}{l}\text { Double-labeled Cells } \\
\left(\% \times 10^{2}\right)\end{array}$} & \multirow{2}{*}{$\begin{array}{l}\text { Actual vs } \\
\text { Predicted }\end{array}$} \\
\hline & & & & Predicted & Actual & \\
\hline & $1547 \mathrm{~L}$ & $9.2(2.8)$ & $6.0(1.8)$ & 5.0 & 9.0 & $>$ \\
\hline & $1553 \mathrm{~L}$ & $31.1(7.3)$ & $22.0(5.0)$ & 35.0 & 67.0 & $>$ \\
\hline & $1554 \mathrm{~L}$ & $30.7(7.3)$ & $18.0(4.0)$ & 28.0 & 74.0 & $>$ \\
\hline \multirow[t]{2}{*}{ E13/HRP D3 } & $1502 \mathrm{~L}$ & $3.7(0.8)$ & $18.0(3.7)$ & 3.0 & 0.3 & $<$ \\
\hline & $1556 \mathrm{~L}$ & $23.1(5.0)$ & $28.0(5.6)$ & 26.0 & 0 & $<$ \\
\hline
\end{tabular}

${ }^{a}$ Treatment is given as age at thymidine injection/age at HRP placement.

tested in experiment 2 , since it is not possible to selectively label the later arriving axons with HRP in an intact animal. The axons of cells formed on E11 are in (and may be expanding within) their projection regions by P3. Very few axons of cells formed on E13 have reached this level by P3. By adding a tract section on P3, the early arriving axons would be cut. If only the late arriving axons grow through the cut, these fibers and their cells of origin will be preferentially labeled by HRP injection in the olfactory cortex one month later. If our hypothesis 


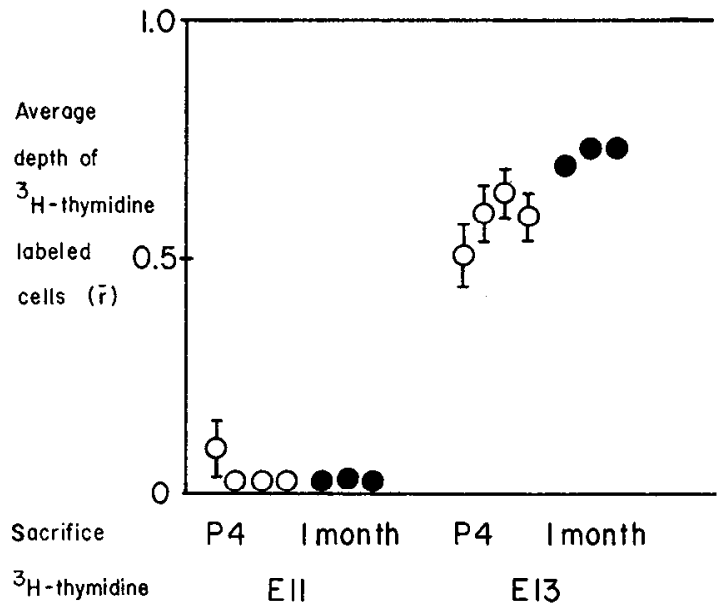

Figure 6. Positions of heavily labeled cells following $\left[{ }^{3} \mathrm{H}\right]$ thymidine injections on E11 or E13. Animals were sacrificed at either $\mathrm{P} 4$ or about 1 month. Each circle represents $\bar{r} \pm \mathrm{SEM}$ for one animal. The value of $\vec{r}$ for E13, P4 is reduced compared to that for E13, 1 month. Details are in the text.

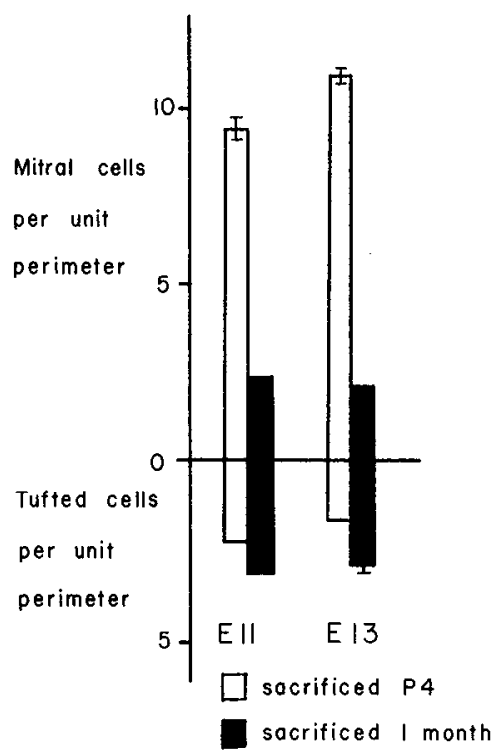

Figure 7. Change in the ratio of mean total number \pm SEM (labeled and unlabeled) of mitral to tufted cells between P4 and 1 month. Animals received injections of $\left[{ }^{3} \mathrm{H}\right]$ thymidine on E11 or E13. At P4, there are many more mitral than tufted cells, but the ratio is reversed at 1 month. At $\mathrm{P} 4$, the number of cells in the mitral cell layer is greater in the E13 animals than in the E11 animals.

is to be supported, the number of cells labeled with both $\left[{ }^{3} \mathrm{H}\right]$ thymidine and HRP should be much greater in the group with $\left[{ }^{3} \mathrm{H}\right]$ thymidine injection on E13 than the one on E11.

Results. The results do not support the hypothesis. They demonstrate, instead, that cells formed on E11, but not on E13, are able to reinnervate the olfactory cortex (Table III). Two of the E11 animals had more doublelabeled cells than would be predicted based on a random association of the birth date and axonal uptake of HRP. One animal had fewer than predicted double-labeled cells, while the fourth animal had no double-labeled cells.
None of the animals that received $\left[{ }^{3} \mathrm{H}\right]$ thymidine injections on E13 had any double-labeled cells. Few cells formed on E13 were projecting through the level of the tract section at P3 (the time of the cut), and there was no evidence that any subsequently passed through the cut and later scar.

Several other effects of LOT section on P3 were observed. Tract section on $\mathrm{P} 3$ in animals that had $\left[{ }^{3} \mathrm{H}\right]$ thymidine-labeled injections on E13 produced a decrease in the average depth of $\left[{ }^{3} \mathrm{H}\right]$ thymidine-labeled cells in the EPL, as compared to animals with no tract section (Fig. 8). The value of $\bar{r}$ in LOT section animals is 0.59 , as compared to 0.72 for intact animals $(t=4.67, p<0.001)$. The cells formed on E13 do not move as far into the EPL after tract section as they do in the normal animal. There was no change in the $\bar{r}$ of labeled cells in the animals with tract sections injected with $\left[{ }^{3} \mathrm{H}\right]$ thymidine on E11.

Both the E11 and E13 $\left[{ }^{3} \mathrm{H}\right]$ thymidine groups have a decreased number of total (unlabeled) mitral cells per unit perimeter following LOT section (Fig. 9). The mitral cells are formed early (E11 and E12) and are likely to have had their axons severed by the LOT section. The number of tufted cells is increased in the E13 $\left[{ }^{3} \mathrm{H}\right]$ thymidine animals, but not in the E11 animals. Recall that

TABLE III

Proportions of double-labeled cells after LOT transection

\begin{tabular}{|c|c|c|c|c|}
\hline \multirow{2}{*}{ 'I'reatment" } & \multirow{2}{*}{ Brain } & \multicolumn{2}{|c|}{$\begin{array}{l}\text { Double-labeled Cells } \\
\qquad\left(\% \times 10^{2}\right)\end{array}$} & \multirow{2}{*}{$\begin{array}{l}\text { Actual vs. } \\
\text { Predicted }\end{array}$} \\
\hline & & Predicted & Actual & \\
\hline \multirow[t]{4}{*}{ E11/LOT P3/HRP } & $1670 \mathrm{~L}$ & 1.6 & 0.3 & $<$ \\
\hline & $1674 \mathrm{~L}$ & 0.4 & 0.9 & $>$ \\
\hline & $1675 \mathrm{~L}$ & 0.1 & 0 & $<$ \\
\hline & $1684 \mathrm{~L}$ & 0.8 & 1.4 & $>$ \\
\hline \multirow[t]{4}{*}{ E13/LOT P3/HRP } & $1579 \mathrm{~L}$ & 2.2 & 0 & $<$ \\
\hline & $1580 \mathrm{~L}$ & 4.8 & 0 & $<$ \\
\hline & 1743L & 0.04 & 0 & $<$ \\
\hline & $1747 \mathrm{I}_{4}$ & 0 & 0 & $<$ \\
\hline
\end{tabular}

${ }^{a}$ Treatment is given as age at $\left[{ }^{3} \mathrm{H}\right]$ thymidine injection/age at LOT transection/HRP placement at 1 month of age.

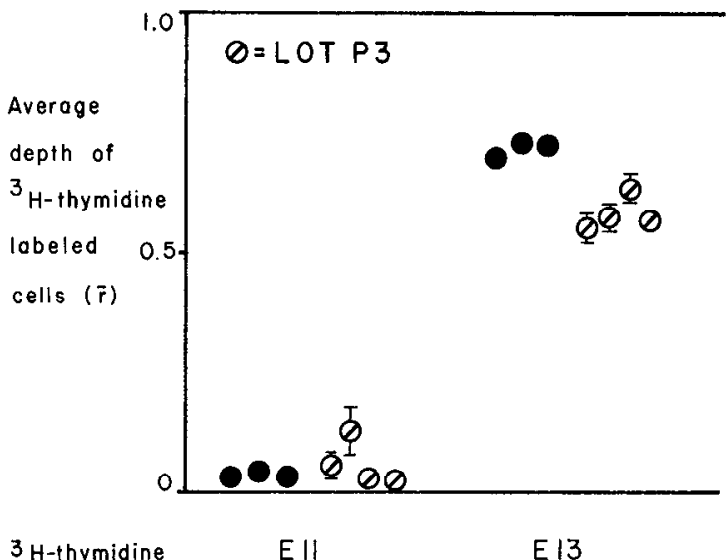

Figure 8. Positions of heavily labeled cells after transection of the LOT at P3 (LOT P3). Animals received injections of $\left[{ }^{3} \mathrm{H}\right]$ thymidine on E11 or E13. All animals were sacrificed at about 1 month of age. Each circle represents $\bar{r} \pm$ SEM for one animal. The solid circles represent intact animals. The value of $\bar{r}$ is reduced following LOT section in the E13 animals. 


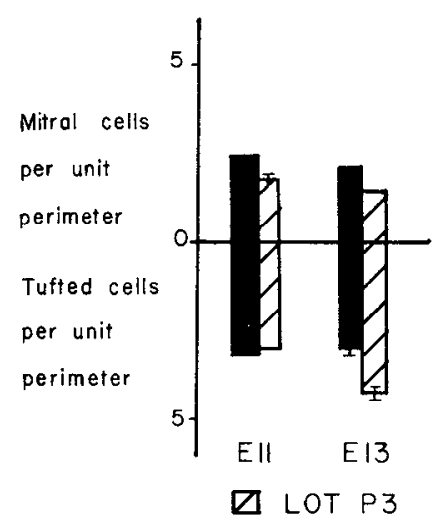

Figure 9. The ratio of total mitral to tufted cells in animals with (hatched bars) or without (solid bars) P3 LOT section (LOT P3). Animals were injected with $\left[{ }^{3} \mathrm{H}\right]$ thymidine on E11 or E13, and all were sacrificed at about 1 month of age. Both E11 and E13 groups have a decreased number of mitral cells, and the E13 animals have an increased number of tufted cells after LOT section.

animals in experiment 2 that were injected with $\left[{ }^{3} \mathrm{H}\right]$ thymidine on E13 and sacrificed on day 4 had more cells in the MCL than did E11 $\left[{ }^{3} \mathrm{H}\right]$ thymidine animals. The injection of $\left[^{3} \mathrm{H}\right]$ thymidine on E13 appears to have an effect on the positions of cells destined for the EPL that have yet to undergo their final division (see M. R. Grafe, submitted for publication). Examination of the numbers of $\left[{ }^{3} \mathrm{H}\right]$ thymidine-labeled cells in brains with and without tract sections reveals that there is no loss of either E11 or E13 $\left[{ }^{3} \mathrm{H}\right]$ thymidine-labeled cells. The loss of mitral cells following LOT section is apparently due to the loss of cells which were born between these two injection times, or on E12, broadly speaking.

Tract section also had no effect on the mean width of the EPL. A normal, age-related change in width occurs between $\mathrm{P} 4$ and 1 month, but this increase was not affected by tract section on $\mathrm{P} 3$.

\section{Discussion}

Time of mitral and tufted cell formation. The mitral and tufted cells of the hamster olfactory bulb undergo their last divisions between E10 and E14. Mitral cells are formed primarily on E11 and E12, and tufted cells are formed on E11 to E14. In the mouse olfactory bulb (Hinds, 1968) mitral cells are formed on E10 to E15, peaking at E13, and tufted cells are formed on E10 to E18, peaking at E16. The period of histogenesis in the hamster is both earlier and more compact than that of the mouse. The golden hamster is born after an extremely short gestational period of 16 days. This is one of the shortest gestational periods of all rodents (Graves, 1945). In view of the hamster's immaturity at birth, it was expected that mitral and/or tufted cells would continue to divide in the early postnatal period. The results support, instead, the concept of a more compressed, rapid period of prenatal development. The olfactory bulbs of both the hamster and the mouse appear to be at a similar stage of histogenetic development at the time of birth.

In a preliminary analysis of the data, an attempt was made to classify the large cells in the external plexiform layer as either inner, middle, or outer tufted cells, as has been done previously (Ramon y Cajal, 1911; Hinds, 1968).
The initial analysis showed that the inner tufted cells were more closely related to the mitral cells in their time of origin than to the middle and outer tufted cells. The histological appearance in Nissl and Golgi stains of the inner tufted cells is very similar to that of the mitral cells. The depth analysis in this experiment demonstrates that there is also no clear histogenetic distinction between mitral and tufted cells, but rather a continuum of cells from the MCL through the EPL. The distinction between mitral and tufted cells was originally based on their positions in different layers of the bulb (Ramon y Cajal, 1911). Although it is now known that tufted cells project to olfactory cortical regions along with the mitral cells, rather than to the contralateral olfactory bulb (Lohman and Mentink, 1969), there are differences in the distribution of their projections. Evidence from HRP and electrophysiological studies indicates that tufted cells, especially middle and outer tufted cells, project more heavily to the olfactory tubercle than to the piriform cortex (Haberly and Price, 1977; Scott et al., 1980; Scott, 1981). The relationship of these differential projections to the functional organization of the bulb or projection areas is yet to be determined.

One limitation to the present analysis is that $\left[{ }^{3} \mathrm{H}\right]$ thymidine has only been injected at $24-\mathrm{hr}$ intervals. The cell cycle of hamster cortical neurons has been estimated to be about $12 \mathrm{hr}$, with an S phase (the time of DNA synthesis when $\left[{ }^{3} \mathbf{H}\right]$ thymidine is incorporated) of about $6 \mathrm{hr}$ (Shimada and Langman, 1970). It is not known if CNS cells cycle in synchrony. Injection of $\left[{ }^{3} \mathrm{H}\right]$ thymidine at 24-hr intervals illuminates fairly narrow "windows" of cell formation and labels only a fraction of the cells which actually go through their last S phase on that day.

Correlation of birth date and axonal projection. The second experiment demonstrated that in the hamster olfactory system, the axons of early formed olfactory bulb cells reach the olfactory cortex before the axons of late formed cells. The correlation of time of cell formation with axonal projections has been suggested in the rat retina but is based on indirect evidence from diverse techniques. Cell formation in the retina generally proceeds from central to peripheral regions (Sidman, 1961), and Golgi studies show that axons from the central retina project into the optic tract before peripheral retinal axons (Morest, 1970). Removal of one eye at birth produces an aberrant increased projection to the ipsilateral superior colliculus, while enucleation at P5 results in an ipsilateral projection only to those areas innervated by the peripheral retina, again suggesting that the peripheral axonal projection develops later than the central projection (Lund et al., 1973). The present report is believed to be the first demonstration of the correlation of time of cell formation and axonal projection in individual cells. This knowledge was an important prerequisite for experiment 3.

The combination of the $\left[{ }^{3} \mathrm{H}\right]$ thymidine and HRP labcling, each of which labcls only a fraction of the possible cell population, results in a fairly low expected proportion of double-labeled cells. In experiment 2 the average predicted proportion of double-labeled cells was about $0.15 \%$. There were about 350 to 400 mitral and tufted cells per section, which gives an expected frequency of approximately one double-labeled cell every two sections. Since 
about 200 sections were examined for each olfactory bulb in this experiment, the very low expected percentages translate into ample numbers of cells. The early formed cells (E11) were double-labeled with a higher probability than predicted, while the late-formed cells were labeled considerably less than predicted.

Reinnervation after transection of the LOT. After transection of the LOT at P3, axons of cells formed on E11 are able to grow through the cut and reinnervate the olfactory cortex. No axons of cells formed on E13, on the other hand, were found to reinnervate the region caudal to the cut. Many of the E11 cells have axons which are already in the projection areas at the time of the transection and would thus be cut by this procedure. Some axons of E11 cells may be well arborized along the course of the LOT, with established connections, whereas others may be just entering the region on their way to their final targets. Few axons of E13 cells have reached the level of the transection (which was generally at the level of the rostral olfactory tubercle) by P3.

Using autoradiographic methods to determine the LOT projection, Schwob and Price (1978) found that the LOT in the rat first innervates the region deep to the LOT and then expands laterally, caudally, and medially. The data reported here suggest that the axons with the most extensive projections (from E11 cells), rather than those that have not yet reached the region (from E13 cells), are the ones able to grow through the site of an early tract section. The projections rostral to the level of the cut (to the anterior olfactory nucleus and rostral olfactory tubercle) are probably not extensively arborized at P3 but may be sufficient to provide "sustaining collaterals" to support the cell.

There may be other more mature features of the early formed cells and their axons which help to maintain the cell and allow axonal regrowth. It is likely that the terminal fields are reinnervated by collateral sprouts from proximal branches of the transected fibers. The formation of collateral sprouts from both the proximal branches of the severed axons and nearby undamaged axons after lesions in young animals is now a well established phenomenon (see, for example, Bjorklund et al., 1971; Lynch et al., 1973; Schneider, 1973; Pickel et al., 1974; Devor, 1976b; Kalil and Reh, 1979). Following an early LOT section, Devor (1976b) found both proximal collateral sprouting (rostral to the cut) and sprouting from the association system fibers caudal to the cut. It is possible that some of the proximal sprouts are able to continue through the cut into the more caudal projection regions. Axons of the later formed cells (E13), which apparently cannot grow through the cut or subsequent scar, may contribute to the increased density of innervation rostral to the cut, since these cells do not die. There was a loss of mitral cells following LOT section, apparently due to the loss of mitral cells formed on E12. These cells may have had their axons severed by the cut but did not have sufficient proximal arborization (or maturity) to maintain the cell's viability.

Other effects of lateral olfactory tract transection. When a tract section is done on P3, some of the cells of origin in the bulb, especially tufted cells, have not yet completed their migration (as shown in Figs. 6 and 7). By P4, there are more cells in the mitral cell layer than in the EPL. As the perimeter of the MCL increases, the thickness of the MCL decreases. 'The reversal in the ratio of mitral to tufted cells, such that at 1 month of age there are more tufted than mitral cells, indicates that many cells in the MCL at P4 are actually passing through the MCL and will eventually be located in the EPI. Figure 7 shows additionally that the number of cells in the MCL at P4 is greater in animals injected with $\left[{ }^{3} \mathrm{H}\right]$ thymidine on E13 than on E11. Transection of the LOT at P3 results in a change of position within the EPL of cells labeled with $\left[{ }^{3} \mathrm{H}\right]$ thymidine on E13. These cells have not moved as far into the EPL as they normally would have (Fig. 8). In addition, the number of total (labeled and unlabeled) tufted cells is increased after LOT section in animals given $\left[{ }^{3} \mathrm{H}\right]$ thymidine on $\mathrm{E} 13$, but not those injected on E11. This suggests that the altered position at the time of tract section of a cell destined for the EPL affects the final position the cell achieves. A possible mechanism for this effect is proposed by Grafe (submitted for publication).

Possible mechanisms of reinnervation after early le. sions. These experiments show that the axons of early formed cells that have reached the olfactory projection regions early are able to reinnervate these regions after tract section on P3. One question which has not been answered by these experiments is why the LOT axons are not able to regrow and reinnervate the projection regions when the tract is cut after P7. Their failure apparently is not due to the normal termination of new axons growing into the area at this time. Other experiments have shown that while the capacity for regrowth progressively decreases to P7 (Devor, 1976b), there is still a large increase in the innervation of the olfactory cortex after P7 (Grafe and Leonard, 1982; Schoenfeld and Leonard, 1979). From the experiments reported here, it appears that the proximal parts of the more mature axons are better able to survive the transection and then move through the cut or scar. Mature axons do retain some capacity for collateral sprouting (Lynch et al., 1973); Barker and Ip (1966) found that "motor axons in mammals undergo collateral and ultraterminal sprouting under normal conditions" as well as when they are deafferented. Since axonal regrowth occurs primarily in young animals, but only from the more mature cells, it is possible that there is some "critical period" in the neuron's development that is optimal for axonal regrowth. A more likely possibility is that there are critical developmental changes which affect the interactions between the axons and the tissue into which the axons are growing. The immaturity of the tissue may permit regenerating afferent axons to grow and establish connections.

The end of the first postnatal week is approximately the time when lesions begin to produce long-lasting degeneration argyrophilia in the olfactory projections (Leonard, 1975). The developing persistence of degenerating fibers could influence the ability of axons to reinnervate the area (Westrum, 1980). During this time there is also an increase in the growth of the olfactory association projections (Price et al., 1976; Singh, 1977; Schoenfeld et al., 1981). Regrowing axons may not be able to compete as well for synaptic space with association axons which had never been interrupted. It is intriguing to note that in the hamster olfactory system, the age at which 
regeneration of the LOT no longer occurs roughly corresponds to the time when radial glial fibers are no longer present in the lateral part of the olfactory tubercle (Grafe and Schoenfeld, 1982). In many other systems, it appears that both developing and regenerating axons are guided by channels formed by ependymal and glial cells and their processes (Henrickson and Vaughn, 1974; Nordlander and Singer, 1982; Silver and Sidman, 1980; Singer et al., 1979; Turner and Singer, 1974). The glial and connective tissue scar which forms after CNS injury has been recognized for many years to interact with axonal regenerative attempts (Windle, 1956). The scar is not an absolute barrier to regenerating fibers, however, since regenerating adrenergic axons can grow through a scar (Bjorklund et al., 1971; Nygren et al., 1971). The early descriptions by Ramon y Cajal (1928) of regenerative attempts report that axons can grow into the scar, but then stop their growth. Windle (1956) and Puchala and Windle (1977) review pharmacological manipulations which allow axons to grow into the region of the scar, but these axons also do not survive. There may be developmental changes in the density or composition of the scar, or in the presence and form of phagocytic cells in the region of the scar, but the effects that these factors may have on axonal regeneration are not clear.

If the potential for reinnervation had been shown to be limited by the period of axonal growth, the possibility for functional recovery would be quite limited. The results af this study thus add a positive note to the current views of the restorative capacities of the CNS. The difficult questions of what the critical developmental factors influencing axonal regrowth are and whether they can be modified in a functionally beneficial manner remain to be investigated.

\section{References}

Adams, J. C. (1977) Technical considerations of the use of horseradish peroxidase as a neuronal marker. Neuroscience 2: 141-145.

Altman, J. (1969) Autoradiographic and histologic studies of postnatal neurogenesis. IV. Cell proliferation and migration in the anterior forebrain, with special reference to persisting neurogenesis in the olfactory bulb. J. Comp. Neurol. 137: 433-458.

Barber, P. C. (1981) Axonal growth by newly-formed vomeronasal neurosensory cells in the normal adult mouse. Brain Res. 216: 229-237.

Barker, D., and M. C. Ip (1966) Sprouting and degeneration of mammalian motor axons in normal and deafferented skeletal muscle. Proc. R. Soc. Lond. (Biol.) 163: 538-554.

Bernstein, J. J., and D. C. Goodman (1973) Neuromorphological plasticity. Brain Behav. Evol. 8: 4-161.

Bjorklund, A., R. Katzman, U. Stenevi, and K. A. West (1971) Development and growth of axonal sprouts from noradrenalin and 5-hydroxytrypamine neurones in the rat spinal cord. Brain Res. 31: 21-33.

Blass, E. M., M. H. Teicher, C. P. Cramer, J. P. Bruno, and W. G. Hall (1977) Olfactory, thermal and tactile controls of suckling in preauditory and previsual rats. J. Comp. Physiol. Psychol. 91: 1248-1260.

Bregman, B. S., and M. E. Goldberger (1982) Anatomical plasticity and sparing of function after spinal cord damage in neonatal cats. Science 217: 553-555.

Crandall, J. E., and C. M. Leonard (1979) Developmental changes in thermal and olfactory influences on golden hamster pups. Behav. Neural Biol. 26: 354-363.

Devor, M. (1975) Neuroplasticity in the sparing or deterioration of function after early olfactory tract lesions. Science 190: 998-1000.

Devor, M. (1976a) Fiber trajectories of olfactory bulb efferents in the hamster. J. Comp. Neurol. 166: 31-48.

Devor, M. (1976b) Neuroplasticity in the rearrangement of olfactory tract fibers after neonatal transection in hamsters. J. Comp. Neurol. 166: 49-72.

Devor, M., and G. E. Schneider (1974) Attraction to home-cage odor in hamster pups: Specificity and changes with age. Behav. Biol. 10: 211-221.

Grafe, M. R., and C. M. Leonard (1982) Developmental changes in the topographical distribution of cells contributing to the lateral olfactory tract. Dev. Brain Res. 3: 387-400.

Grafe, M. R., and T. A. Schoenfeld (1982) Radial glial cells in the postnatal olfactory tubercle of hamsters. Dev. Brain Res., 4: $115-118$.

Graves, A. P. (1945) Development of the golden hamster, Cricetus auratus Waterhouse, during the first nine days. Am. J. Anat. 77: 219-251.

Graziadei, P. P. C., R. R. Levine, and G. A. Monti-Graziadei (1979) Plasticity of connections of the olfactory sensory neuron: Regeneration into the forebrain following bulbectomy in the neonatal mouse. Neuroscience 4: 713-727.

Guillery, R. W. (1972) Experiments to determine whether retinogeniculate axons can form translaminar collateral sprouts in the dorsal lateral geniculate nucleus of the cat. J. Comp. Neurol. 146: 407-420.

Guth, L., and C. D. Clemente (1975) Growth and regeneration in the central nervous system. Exp. Neurol. 48(No. 3, Part 2): $1-251$.

Haberly, L. B., and J. L. Price (1977) The axonal projection patterns of mitral and tufted cells of the olfactory bulb in the rat. Brain Res. 129: 152-157.

Henrickson, C. K., and J. F. Vaughn (1974) Fine structural relationships between neurites and radial glial processes in developing mouse spinal cord. J. Neurocytol. 3: 659-675.

Hicks, S. P., and C. J. d'Amato (1970) Motor-sensory and visual behavior after hemispherectomy in newborn and mature rats. Exp. Neurol. 29: 416-438.

Hinds, J. W. (1968) An autoradiographic study of histogenesis in the mouse olfactory bulb. I. Time of origin of neurons and neuroglia. J. Comp. Neurol. 134: 287-304.

Kalil, K., and T. Reh (1979) Regrowth of severed axons in the neonatal central nervous system: Establishment of normal connections. Science 205: 1158-1161.

Leonard, C. M. (1975) Developmental changes in olfactory bulb projections revealed by degeneration argyrophilia. J. Comp. Neurol. 162: 467-486.

Leonard, C. M. (1978) Maturational loss of thermotaxis prevented by olfactory lesions in golden hamster pups (Mesocricetus auratus). J. Comp. Physiol. Psychol. 92: 1084-1094.

Lohman, A. H. M., and G. M. Mentink (1969) The lateral olfactory tract, the anterior commissure, and the cells of the olfactory bulb. Brain Res. 12: 396-413.

Lund, R. D., T. J. Cunningham, and J. S. Lund (1973) Modified optic projections after unilateral eye removal in young rats. Brain Behav. Evol. 8: 51-72.

Lynch, G., B. Stanfield, and C. W. Cotman (1973) Developmental differences in post-lesion axonal growth in the hippocampus. Brain Res. 59: 155-168.

Mesulam, M. -M. (1978) Tetramethyl benzidine for horseradish peroxidase neurohistochemistry: A non-carcinogenic blue reaction product with superior sensitivity for visualizing neural afferents and efferents. J. Histochem. Cytochem. 26: 106-117.

Moody, S. A., and M. B. Heaton (1981) Morphology of migrating trigeminal motor neuroblasts as revealed by horseradish 
peroxidase retrograde labeling techniques. Neuroscience 6 : 1701-1723.

Morest, D. K. (1970) The pattern of neurogenesis in the retina of the rat. Z. Anat. Entwickl. 131:45-67.

Nordlander, R. J., and M. Singer (1982) Spaces precede axons in Xenopus embryonic spinal cord. Exp. Neurol. 75: 221-228.

Nowakowski, R. S., J. H. LaVail, and P. Rakic (1975) The correlation of origin of neurons with their axonal projection: The combined use of ${ }^{3} \mathrm{H}$-thymidine autoradiography and HRP histochemistry. Brain Res. 99: 343-348.

Nygren, L. G., L. Olson, and A. Seiger (1971) Regeneration of monoamine-containing axons in the developing and adult spinal cord of the rat following intraspinal 6-hydroxydopamine injections or transections. Histochem. 28: 1-15.

Pickel, V. M., M. Segal, and F. E. Bloom (1974) Axonal proliferation following lesions of cerebellar peduncles. A combined fluorescence microscopic and radioautographic study. J. Comp. Neurol. 155: 43-60.

Price, J. L., G. F. Moxley, and J. E. Schwob (1976) Development and plasticity of complementary afferent fiber systems to the olfactory cortex. Exp. Brain Res. Suppl. 1: 148-154.

Puchala, E., and W. F. Windle (1977) The possibility of structural and functional restitution after spinal cord injury. A review. Exp. Neurol. 55: 1-42.

Ramon y Cajal, S. (1911) Histologie du Systeme Nerveux de l'Homme et des Vertebres, Volume II, Consejo Superior de Investigaciones Cientificas, Madrid. Reprinted 1955.

Ramon y Cajal, S. (1928) Degeneration and Regeneration of the Nervous System, Hafner Publishing Co., New York. Reprinted 1959.

Ranson, S. W. (1903) On the medullated nerve fibers crossing the site of lesions in the brain of the white rat. J. Comp. Neurol. 13: 185-205.

Rudy, J. W., and M. D. Cheatle (1977) Odor-aversion learning in neonatal rats. Science 198: 845-846.

Schneider, G. E. (1973) Early lesions of superior colliculus: Factors affecting the formation of abnormal retinal projections. Brain Behav. Evol. 8: 73-109.

Schoenfeld, T. A., and C. M. Leonard (1979) Postnatal synaptic development in the olfactory tubercle of the golden hamster. Anat. Rec. 193: 677.

Schoenfeld, T. A., J. V. Corwin, and C. M. Leonard (1981) Regionally specific alterations in the growth of olfactory cortex following neonatal bulbectomy in golden hamsters. Soc. Neurosci. Abstr. 7: 539.

Schwob, J. E., and J. L. Price (1978) The cortical projection of the olfactory bulb: Development in fetal and neonatal rats correlated with quantitative variations in adult rats. Brain Res. 151: 369-374.

Scott, J. W. (1981) Electrophysiological identification of mitral and tufted cells and distributions of their axons in the olfac- tory system of the rat. J. Neurophysiol. 46: 918-931.

Scott, J. W., R. L. McBride, and S. P. Schneider (1980) The organization of projections from the olfactory bulb to the piriform cortex and olfactory tubercle in the rat. J. Comp. Neurol. 194: 519-534.

Shimada, M., and J. Langman (1970) Cell proliferation, migration and differentiation in the cerebral cortex of the golden hamster. J. Comp. Neurol. 139: 227-244.

Sidman, R. L. (1961) Histogenesis of mouse retina studied with thymidine- ${ }^{3} \mathrm{H}$. In The Structure of the Eye, G. K. Smelsen, ed., pp. 487-505, Academic Press, Inc., New York.

Sidman, R. L. (1970) Autoradiographic methods and principles for study of the nervous system with thymidine $\mathrm{H}^{3}$. In Contemporary Research Methods in Neuroanatomy, W. J. H. Nauta and S. O. E. Ebbeson, eds., pp. 252-274, SpringerVerlag, New York.

Silver, J., and R. L. Sidman (1980) A mechanism for the guidance and topographic patterning of retinal ganglion cell axons. J. Comp. Neurol. 189: 101 111.

Singer, M., R. H. Nordlander, and M. Egar (1979) Axonal guidance during embryogenesis and regeneration in the spinal cord of the newt: The blueprint hypothesis of neural pathway patterning. J. Comp. Neurol. 185: 1-22.

Singh, D. N. P., and E. J. H. Nathaniel (1977) Postnatal development of mitral cell perikaryon in the olfactory bulb of the rat. A light and ultrastructural study. Anat. Rec. 189: 413-432.

Singh, S. C. (1977) The development of olfactory and hippocampal pathways in the brain of the rat. Anat. Embryol. 151: 183-199.

Small, R. (1977) Functional and anatomical reorganization in neonatal hamsters after early olfactory lesions. Doctoral dissertation, City University of New York, New York.

So, K. F. (1979) Development of abnormal recrossing retinotectal projections after superior colliculus lesions in newborn Syrian hamsters. J. Comp. Neurol. 186: 241-258.

Stenevi, U., A. Bjorklund, and R. Y. Moore (1973) Morphological plasticity of central adrenergic neurons. Brain Behav. Evol. 8: 110-134.

Turner, J. E., and M. Singer (1974) The ultrastructure of regeneration in the severed newt optic nerve. J. Exp. Zool. 190: 249-268.

Westrum, L. E. (1975) Electron microscopy of synaptic structures in olfactory cortex of early postnatal rats. J. Neurocytol. 4: 713-732.

Westrum, L. E. (1980) Alterations in axons and synapses of olfactory cortex following olfactory bulb lesions in newborn rats. Anat. Embryol. 160: 153-172.

Windle, W. F. (1956) Regeneration of axons in the vertebrate central nervous system. Physiol. Rev. 36: 426-440. 